\title{
Electrical Properties of Large Alumina Ceramics Prepared by Various Processing
}

\author{
Kyeong-Sik Cho ${ }^{\dagger}$, Hyun-Kwuon Lee, Young-il Park, and Mi-Young Kim* \\ School of Advanced Materials and System Engineering, Kumoh National Institute of Technology, Gumi 730-701, Korea \\ *Wonik Quartz Co., Gumi 730-933, Korea \\ (Received February 6, 2012; Revised March 5, 2012; Accepted March 7, 2012)
}

\section{제조 공정별 대형 알루미나 세라믹스의 전기적 특성

\author{
조경식 ${ }^{\dagger} \cdot$ 이현권 · 박용일 · 김미영* \\ 금오공과대학교 신소재시스템공학부 \\ *(주)원익쿼츠
} \\ (2012년 2월 6일 접수 ; 2012년 3월 5일 수정 ; 2012년 3월 7일 채택)}

\begin{abstract}
The size of various alumina ceramics used in semiconductor and display industry is required to increase with increase in wafer and panel size. In this research, large alumina ceramics were fabricated by uniaxial pressing, cold isostatic pressing and filter pressing with commercial powder and thereafter sintering at $1600^{\circ} \mathrm{C}$ in gas furnace. The large alumina ceramics exhibited dense microstructure corresponding to $98.5 \%$ of theoretical density and $99.8 \%$ of high purity. The impurities and microstructural defects of the alumina were found to influence the resistance and dielectric properties. The volume resistances in these four aluminas were almost the same while the pure alumina was higher value. The dielectric constant, dielectric loss and dielectric strength of aluminas were placed within the range of $10.3 \sim 11.5,0.018 \sim 0.036$, and $10.1 \sim 12.4 \mathrm{kV} / \mathrm{mm}$, respectively.
\end{abstract}

Keywords : Alumina, Dielectric constant, Dielectric loss, Dielectric strength, Volume resistance

\section{1. 서 론}

디스플레이 제품의 대형화 경향에 발맞추어 반도체 및 디스플레이용 대형 평판 세라믹스의 기술개발이 화두가 되고 있으며 특히, TFT-LCD, LED 및 정보통신의 발전에 의해 전자산업용 구조세라믹스의 발전 방향이 결정되고 있다. 반도체와 $\mathrm{LCD}$ 의 대형화, 그리고 $\mathrm{LED}$ 와 정보통신 복잡형상제품의 제조장비에 장착되는 rubbing stage, end effector, center golf tee, electrostatic chuck 등 세라믹 부 품 규격도 그에 비례하여 커지고 형상도 복잡화 되어 소 재물성의 균질 특성과 가공정밀도가 요구된다.

알루미나 세라믹스는 값이 싸서 실용적일뿐만 아니라 거의 불활성 상태로 존재하기 때문에 일반적인 금속이나 플라스틱에 비해 물리적, 화학적, 기계적 및 열적으로 높 은 안정성을 가지고 있다. 화학적 침식에 대한 저항성이 높아 산알칼리 유기용제 등에 거의 영향을 받지 않으며

${ }^{\dagger}$ Corresponding author : Kyeong-Sik Cho

E-mail : kscho@kumoh.ac.kr

Tel : +82-54-478-7737 Fax : +82-54-478-7769
최고 사용온도가 $1,600^{\circ} \mathrm{C}$ 정도를 갖는 특성을 보유하고 있다. 또한 금속재료보다 약 15-20배의 저팽창, 내마모 특 성과 고온고압 및 고주파 영역에서 높은 절연 효과와 낮 은 유전손실을 보유하고 있어 일반적인 기계구조용 뿐만 아니라 반도체 및 디스플레이 제조공정 등에 범용되고 있 다. 그러나 알루미나 세라믹스 소재에서 나타나는 취성파 괴, 열적 열화 한계성은 내구성 및 신뢰성 저하의 문제를 초래하며, 부품이 대형화 될수록 부재의 생산공정, 가공 공정 및 실재 부품으로서의 조립 및 사용 환경에서 문제 점은 더욱 더 심각해진다. 이에 따라 대형 알루미나 세라 믹의 물성 제어기술 확보가 관건이 되고 있다. ${ }^{1,2)}$

대형 알루미나 세라믹스를 산업체에서 제조하는 성형 방법은 일축가압 성형(uniaxial pressing), 냉간정수압 성형 (cold isostatic pressing, CIP), 슬립캐스팅(slip casting)과 필터프레스(filter press)가 대표적이다. ${ }^{3-6)}$ 일축가압 성형은 단순 형상 대량생산 제품을 치수정밀도가 높게 제조할 수 있지만 밀도 균질성 및 크기 대형화에 한계점이 있고, CIP 는 단순 형상 제품을 대량생산 할 수 있는 장점을 가지 고 있지만, 복잡한 형상을 가진 제품을 만들기 힘들고, 후 가공, 초기 투자비용 등에서 문제를 가지고 있다. 슬립캐 
스팅은 형상이 복잡한 모양의 제품을 만들 수 있으므로 다품종 소량생산에 적합한 방법이지만 숙련된 기술 요구 및 석고모듈의 빈번 교체 등에 단점을 갖고 있다. 또한 성형체 생산 능력을 향상시키기 위해 필터프레스로 슬립 을 가압 탈수하여 대형 알루미나 성형체를 제조하는 방 식도 적용되고 있다. 그러므로 각각의 성형 방법에 따라 대형 제품 실현성, 소결조건 뿐 아니라 소재 물성이 크게 달라질 수 있다. 대부분의 경우 공정변수에 따라 소결밀 도, 입자와 기공 등의 크기와 분포를 조절하여, 미세한 결 정립 조직을 갖는 완전 치밀화 소결체를 재현성 있게 제 조하는 것을 목적으로 한다. ${ }^{6,7)}$

대형 알루미나 세라믹스의 생산에서 소성 후 정품 수 율이 낮다는 점이 제약인데, 즉 성형체 그대로의 상태 혹 은 가공 성형체에서 소성되면서 자체 하중 및 가공결함 을 이기지 못하고 파괴되는 경우가 많아 하나의 정품 부 재를 생산하는데 많은 비용이 든다는 것이다. 이는 알루 미나 부재 가격의 상승 요인으로 작용한다. 따라서 높은 수율로 균질한 품질의 대형 알루미나 세라믹스를 제조하 기 위한 노력이 절실히 요구되는 상황이다.

이전의 연구에서는 실제 생산 현장에서 대형 소재를 제 조하기 위해 사용되는 여러 가지 성형공정별 최적 조건 의 알루미나 성형체 및 소결체의 특성을 조사하였고 ${ }^{6)}$ 본 연구에서는 이로부터 제조한 알루미나 소재의 유전성 및 저항 등 전기적 특성을 비교하였다. 대형 알루미나 소재 가 여러 가지 전자산업용 부재로 사용하려면 성형공정별 크기 제한성과 더불어 원료, 제조공정 이력 및 소결 물성 에 관련한 전기적 특성도 정확하게 파악하여 적재적소에 경제적으로 적용하여야 할 것이다.

\section{2. 실험 방법}

산업체에서 알루미나 생산에 직접 적용하는 성형방법 에 따라 적정조건의 분말공정으로 대형 판상 알루미나 소 재를 제조하였다. 알루미나 출발 분말은 순도 $99.8 \%$ 이 상이며, 크기 중앙값 $(\mathrm{d}(50))$ 이 약 $0.5 \sim 1.2 \mu \mathrm{m}$ 인 3종의 상 용 알루미나 분말을 사용하였다.

성형방법을 기준으로 시편을 표기하였는데, $\mathrm{CP}$ 는 냉간 정수압, $\mathrm{PR}$ 은 일축가압, 그리고 $\mathrm{FP} 1, \mathrm{FP} 2$ 는 필터프레스 성형으로 제조한 알루미나이다. 판상 알루미나의 크기와 형상은 $\mathrm{CP}$ 는 높이 $30 \mathrm{~mm}$, 직경 $600 \mathrm{~mm}$ 원형이고 $\mathrm{PR}$ 은 $30 \times 200 \times 500 \mathrm{~mm}$ 사각형이여 $\mathrm{FP} 1$ 과 $\mathrm{FP} 2$ 는 $30 \times 500 \times$ $1000 \mathrm{~mm}$ 사각형 이었다.

성형방법에 따른 판상 알루미나 소결체의 밀도, 순도, 미세구조 및 전기적 특성을 관찰하였는데, 알루미나 세라 믹 부재의 크기에 따라 특성분석 항목별로 6 부위 이상으 로 시편을 채취하여 특성분석의 신뢰성을 높였다. 밀도는 아르키메데스 원리를 이용하여 부피밀도를 측정하고 이
론밀도에 대한 상대밀도로 구하였다. 순도는 KSL 3419에 의해 불순물 유입을 최소화하면서 분쇄하고 가압분해법 으로 전 처리한 후, ICP-AES(Optima 4300, Perkin Elmer, $\mathrm{USA}$ )를 이용하여 측정하였다. 미세조직은 $0.2 \mu \mathrm{m}$ 다이아 몬드 페이스트로 최종 연마하고 $1450^{\circ} \mathrm{C}$ 에서 $20 \sim 60$ 분 동 안 열에칭한 후 FE-SEM(JSM-6500F, JEOL, Japan)으로 관찰하였다.

체적저항은 $3 \times 80 \times 80 \mathrm{~mm}$ 로 시편을 가공하여 HighResistance Meter (6517A, 8009, Kiethley Instruments, USA) 를 이용하여, $25^{\circ} \mathrm{C}$ 의 조건에서 ASTM D-257 방법으로 Fig. 1과 같이 준비하여 측정하였다. 높은 저항을 갖는 알 루미나는 자체 백그라운드 전류가 측정오차의 원인이 될 수 있는데, 장비에 내장된 시퀀스 테스트 기능에 의해 극 성변화와 전압 변화법을 이용하여 오차없이 정확히 측정 할 수 있었다. 즉, 주어진 전압 $(50 \mathrm{~V}, 100 \mathrm{~V}$ 및 $300 \mathrm{~V})$ 의 (+) 바이어스를 인가 후 특정한 지연시간(15초) 후 전류 를 측정하고, 극성을 역전시켜 동일한 지연시간을 이용하 여 전류를 측정하여 측정전류의 가중평균을 취하였으며 다음과 같이 체적저항 $\left(\rho_{\mathrm{v}}, \Omega \cdot \mathrm{m}\right)$ 을 구하였다.

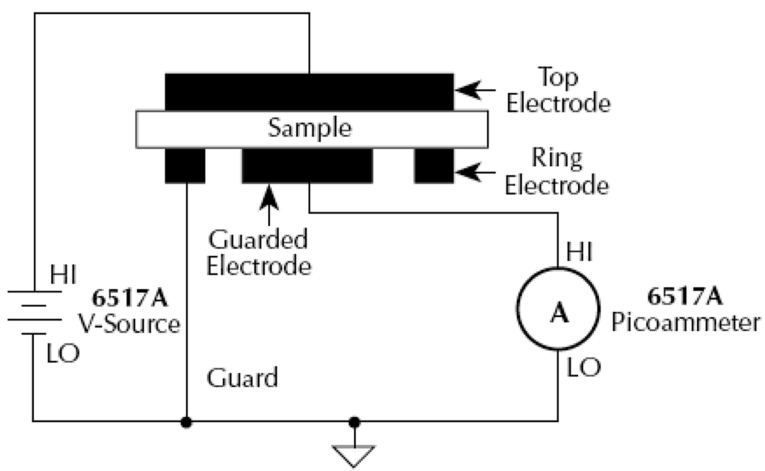

(a)

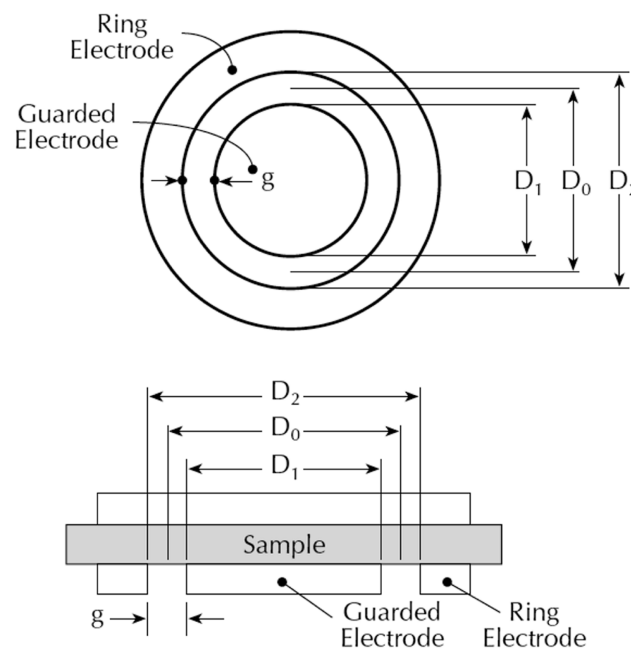

(b)

Fig. 1. Volume resistivity measurement technique (a) and circular electrode dimensions (b). 


$$
\begin{aligned}
& \rho_{\mathrm{v}}=\frac{\mathrm{A}_{\mathrm{d}} \mathrm{R}_{\mathrm{v}}}{\mathrm{A}}=\frac{\pi\left(\mathrm{D}_{1}+\mathrm{g}\right)^{2}}{4} \\
& \mathrm{~g}=\frac{\mathrm{D}_{2}-\mathrm{D}_{1}}{2}
\end{aligned}
$$

여기서 $\mathrm{R}_{\mathrm{v}}$ 는 측정저항 $(\Omega), \mathrm{A}$ 는 주전극의 유효면적 $\left(\mathrm{m}^{2}\right)$, $\mathrm{g}$ 는 주전극과 가드 전극의 사이의 거리 $(\mathrm{m}), \mathrm{d}$ 는 시편의 두께 $(\mathrm{m}) \mathrm{D}_{1}$ 은 주전극의 직경 $(\mathrm{m})$ 및 $\mathrm{D}_{2}$ 는 가드 전극의 직 경 $(\mathrm{m})$ 이다.

유전상수(dielectric constant)와 유전손실(dielectric loss $(\tan \delta))$ 은 직경 $10 \mathrm{~mm}$ 두께 $5 \mathrm{~mm}$ 로 시편 가공하고 은전 극을 처리하고 Impedance Analyser(4991A, Agilent, USA) 를 이용하여, $1 \mathrm{MHz}, 25^{\circ} \mathrm{C}$ 의 조건에서 교정과 보상을 거 친 후 ASTM D-150 방법에 따라 측정하였다. 절연내력 (dielectric strength)은 직경 $10 \mathrm{~mm}$ 두께 $0.5 \mathrm{~mm}$ 로 시편 가 공하고 은전극을 인가한 후 Withstanding Voltage Tester (TOS 5051A, Kikusui, Japan)를 이용하여 $1 \mathrm{MHz}, 25^{\circ} \mathrm{C}$ 의 공기중에서 55 초마다 $0.25 \mathrm{kV}$ 씩 단계적(step by step)으로 전압을 증가시키는 ASTM D-149 B방법에 따라 파괴되는 전압을 측정하였다.

\section{3. 결과 및 고찰}

분무건조 분말을 가압성형 하여 소성한 $\mathrm{CP}$ 와 $\mathrm{PR}$ 은 각 각 $97.0 \%$ 이상의 상대밀도를 나타내었으며, 필터프레스 성형한 $\mathrm{FP} 1$ 과 $\mathrm{FP} 2$ 소결시편은 그보다 약간 낮거나 높은 $95.9 \%$ 와 $98.5 \%$ 이었다.

각각의 방법으로 성형하여 제조한 알루미나 소결체 경 면 미세구조를 Fig. 2에 나타내었다. 전체적으로 2 3 $\mu \mathrm{m}$ 의 등축상 미세입자와 $10 \mu \mathrm{m}$ 이상의 비정상 입성장 조대 결정립으로 구성되어 있으며 입계 기공과 입내 기공도 포 함되어 있는 전형적인 알루미나의 미세구조를 나타내고 있다. 비정상 입성장으로 나타나는 결정립 이중 크기 분포 는 일반적으로 출발분말의 입도분포 조정, $\mathrm{MgO}$ 같은 입 성장 억제제 첨가 그리고 소결분위기의 조절로 효과적으 로 제거할 수 있는 것으로 알려져 있다. ${ }^{7-11)} \mathrm{Fig}$. 2(c)에서 비정상적인 기공 클러스터가 관찰되는데 이는 입도분포가
넓은 출발분말, 슬러리의 분산 상태와 연관된다. 성형체 내 미용해 응집 결합제의 존재에 의해 소성 시 탈지로 인 한 거대 공간으로 형성되어 성형체 내 다른 영역이 치밀 화 되는 동안에도 공간이 치밀화 되지 못해 남게 되는 폐 기공이다. 이러한 미세구조는 소결체의 밀도에 큰 영향을 준 것으로 판단되며 알루미나의 물성을 저하시키는 중요 한 결함이다.

소결 알루미나 시편에 대한 ICP-AES 분석 결과를 Table 1 에 나타내었으며 $99.75 \mathrm{wt} \%$ 이상의 출발분말의 고순도를 소 성 후에도 유지하고 있음을 확인할 수 있다. CP 알루미 나 시편이 불순물의 양이 가장 높고, 나머지 PR, FP1과 FP2 시편의 경우 불순물 혼입이 거의 없는 청정 제조공 정을 유지했음을 보여주는데, 전자산업 제조 장치분야의 부재로 사용할 수 있는 수준의 함량이다.

Fig. 3는 여러 가지 성형법을 거쳐 제조한 각종 알루미 나 시편의 체적저항이다. 각각의 시편에 대해 부위별로 3-5회 반복 측정값의 평균(막대그래프의 진한 색 영역) 및 표준편차(막대그래프의 밝은 색 영역)이다. 알루미나의 체 적저항은 $1.7 \sim 7.2 \times 10^{14} \Omega \cdot \mathrm{cm}$ 의 범위로 알루미나의 고유 한 절연체 특성을 보이고 순도가 낮은 $\mathrm{CP}, \mathrm{PR}$ 시편에 비 해 $\mathrm{FP}$ 시편이 높은 저항을 나타내고 있다.

알루미나의 체적저항은 불순물에 영향을 받는데, 순도

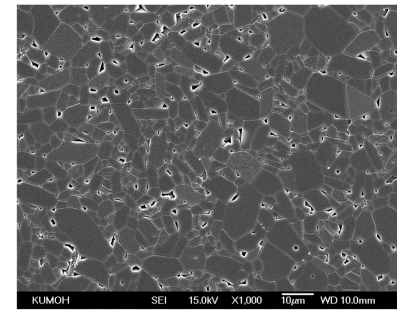

(a)

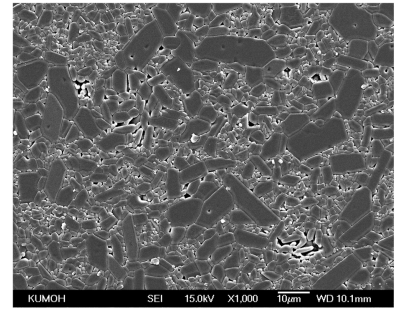

(c)

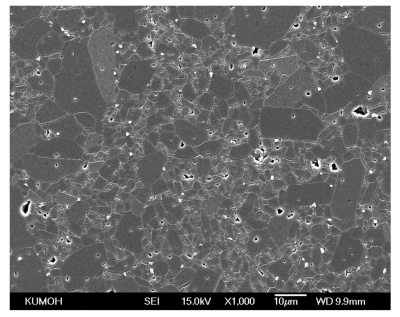

(b)

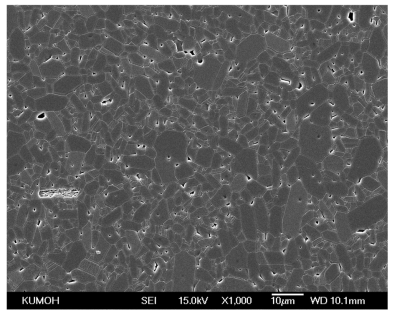

(d)
Fig. 2. Surface microstructures of alumina sintered bodies : (a) CP, (b) PR, (c) FP1, and (d) FP2.

Table 1. Chemical Compositions of Sintered Aluminas Prepared from Various Methods

\begin{tabular}{ccrrrr}
\hline Oxide Base & Chemical Composition (wt\%) & CP & \multicolumn{1}{c}{ PR } & FP1 & FP2 \\
\hline & $\mathrm{Al}_{2} \mathrm{O}_{3}$ & 99.7536 & 99.8232 & 99.9054 & 99.8602 \\
& $\mathrm{MgO}$ & 0.0977 & 0.0943 & 0.0361 & 0.0560 \\
& $\mathrm{Na}_{2} \mathrm{O}$ & 0.0660 & 0.0047 & 0.0188 & 0.0350 \\
& $\mathrm{SiO}_{2}$ & 0.0750 & 0.0684 & 0.0289 & 0.0420 \\
& $\mathrm{Fe}_{2} \mathrm{O}_{3}$ & 0.0077 & 0.0094 & 0.0098 & 0.0068 \\
\hline
\end{tabular}




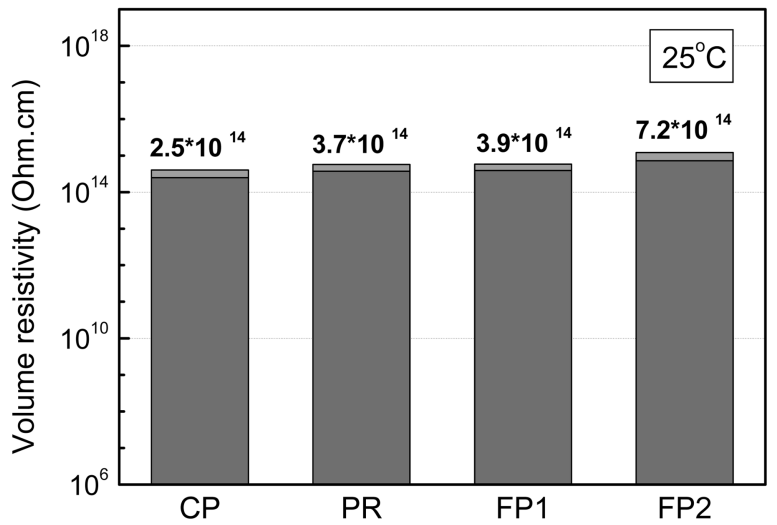

Fig. 3. Volume resistivities of sintered alumina bodies prepared from various methods.

가 높은 알루미나에 비해 불순물이 들어있는 알루미나가 체적저항 값이 낮다. ${ }^{12,13)}$ 특히 $\mathrm{Na}$ 이온이 체적저항을 낮 추는 영향이 크며, $\mathrm{SiO}_{2}$ 는 $\mathrm{CaO}, \mathrm{MgO}, \mathrm{CaO}$ 등에 의한 혼 합 알칼리 효과(mixed alkali effect)에 의해 크게 영향을 끼치지 않는다고 보고된바 있다. ${ }^{14)}$

Figs. 4 와 5 는 여러 가지 성형법으로 제조한 알루미나 소 재의 유전율과 유전손실의 평균(막대그래프의 진한 색 영 역) 및 표준편차(막대그래프의 밝은 색 영역)이다. Figs. 4 와 5 에서 보이는 바와 같이 각각의 성형법으로 제조한 알 루미나의 유전율은 10.3 11.5이고 유전손실은 0.018 0.036 범위이다. 가압성형으로 제조한 시편(CP와 $\mathrm{PR}$ )과 필터프 레싱으로 제조한 시편(FP1와 FP2) 사이에는 유전율의 차 이가 크지 않으나, 유전손실은 가압소결한 알루미나와 같 이 불순물과 구조결함이 많을수록 높았다.

외부의 전기장이 인가되었을 때 부도체가 저장할 수 있는 전하량, 즉 전기적 에너지를 수용하는 유전율 (permittivity, $\varepsilon$ )은 교류전기장 하에서는 다음 식 (4)와 같 이 에너지 파장과 전파에 관련된 실수 항 $\left(\varepsilon^{\prime}\right)$ 과 전기에 너지가 열에너지로 변환되는 과정에서 발생하는 유전손 실에 관련된 허수 항 $(\varepsilon ")$ 으로 표현되며, $j=\sqrt{-1}$ 의 허수 단위이다. 실제로는 유전율 전체 값보다는 편의를 위해 $\varepsilon_{0}$ (공기의 유전율, $8.854 \times 10^{-12} \mathrm{~F} / \mathrm{m}$ )을 제외한 $\varepsilon_{\mathrm{r}}$ 의 비 유전율(relative permittivity) 값만을 특정지표로 사용한다. 부도체에 축적된 전기에너지는 열에너지로 변환되기 때문 에 인가된 전계와 전류 사이의 위상각은 $90^{\circ}$ 이하의 값을 가지므로 $\tan \delta$ 는 부도체의 손실 특성을 규정하는 값이 된 다. 부도체가 외부 전기장에 반응할 때 가해진 전기장 자 체에 반응하는 것이 아니라 장이 가해진 이후 발생하는 일 련의 변화에 반응하는데 유전상수(dielectric constant, $\varepsilon_{\mathrm{r}}^{\prime}$ ) 와 유전손실(dielectric loss, $\tan \delta$ )은 외부 전기장의 주파 수에 대한 복소함수로 표현한다. ${ }^{15)}$

$$
\varepsilon=\varepsilon^{\prime}-j \varepsilon "=\varepsilon_{0} \cdot \varepsilon_{\mathrm{r}}=\varepsilon_{0}\left(\varepsilon_{\mathrm{r}}^{\prime}+j \varepsilon_{\mathrm{r}}^{\prime \prime}\right)
$$

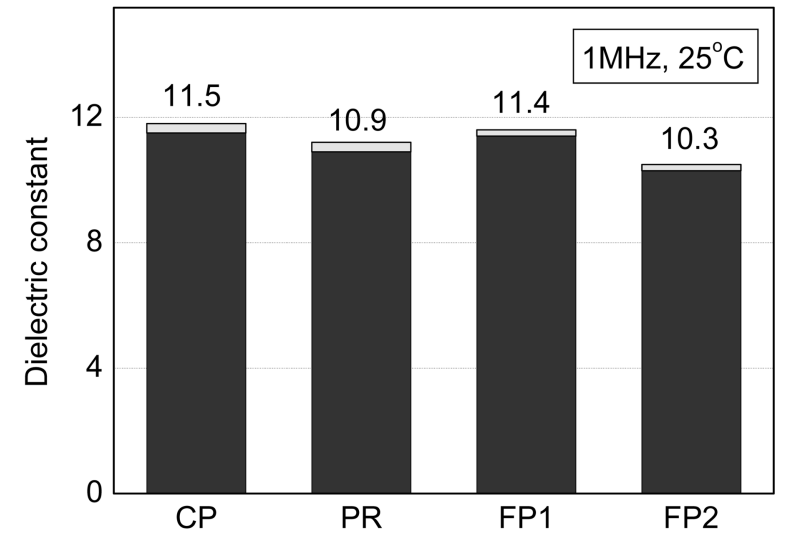

Fig. 4. Dielectric constants of sintered alumina bodies prepared from various methods.

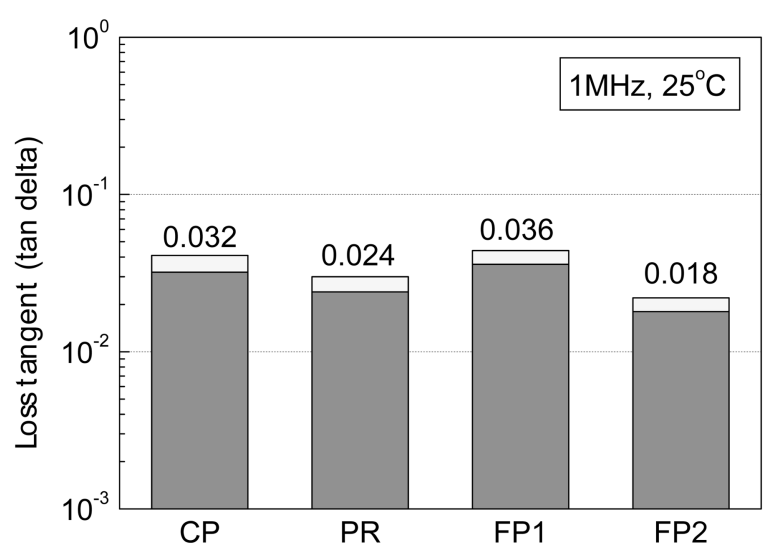

Fig. 5. Dielectric losses of sintered alumina bodies prepared from various methods.

$$
\tan \delta=\frac{\varepsilon_{\mathrm{r}}^{\prime \prime}}{\varepsilon_{\mathrm{r}}{ }^{\prime}}
$$

알루미나의 유전성은 불순물과 구조적 결함에 영향을 받는 것으로 보고되고 있다. 단결정과 다결정 알루미나의 유전상수와 유전손실에 대해 측정한 결과 불순물에 기인 하여 다결정 알루미나가 높다고 하였으며, ${ }^{15)}$ 알루미나의 구성 양이온 $\mathrm{Al}^{3+}$ 와 같은 하전을 띠는 $\mathrm{Cr}^{3+}, \mathrm{Fe}^{3+}$ 등의 불 순물보다 다른 하전을 띠는 불순물이 영향이 더 크다. 특 히 유전상수는 $\mathrm{Mg}^{2+}$, 유전손실은 $\mathrm{Si}^{4+}$ 가 영향을 크게 주 는 것을 보고하였는데, 이는 점결함에 관련된 결함농도를 증가시켜 유전상수와 유전손실을 증가시키는 요인으로 분 석하였다. ${ }^{16)}$ 또한 알루미나 원료 정제 시 필연적으로 존 재하게 되는 $\mathrm{Na}_{2} \mathrm{O}$ 불순물, ${ }^{14)} \mathrm{TiO}_{2}$ 함량에 따라서도 유전 상수와 유전손실을 증진시키며, ${ }^{15)}$ 물론 알루미나 세라믹 스에 순수 알루미나 이외의 다른 2 차 결정상이 존재할 정 도로 불순물 양이 많으면 유전손실을 더욱 증가시키는 결 과도 보고되었다. ${ }^{18-21)}$ 불순물뿐만 아니라 알루미나의 기 공과 구조적 결함도 유전성에 영향을 주는데, 기공률의 


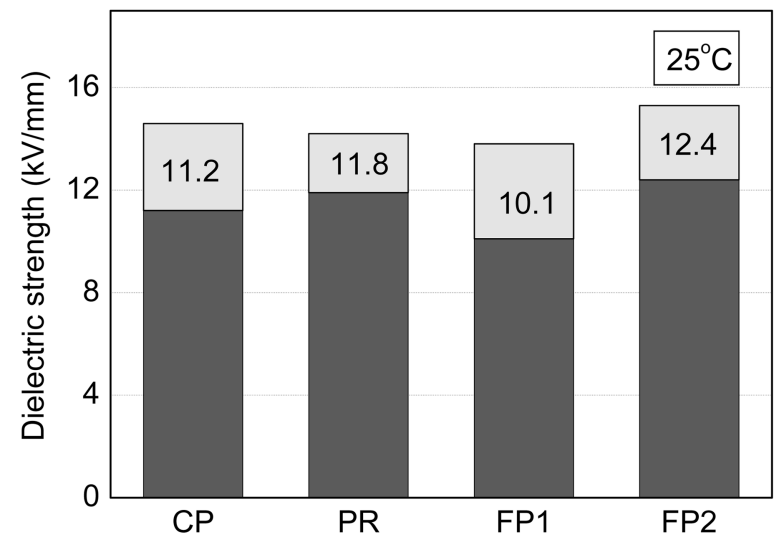

Fig. 6. Dielectric strengths of sintered alumina bodies prepared from various methods.

증가에 따라 유전손실이 상당히 증가한다는 연구가 보고 되었다. ${ }^{18)} \mathrm{TiO}_{2}$ 와 $\mathrm{MgO}$ 를 적절하게 첨가하여 알루미나의 구조적인 치밀성을 증진시키면 유전손실을 감소시킨다는 연구도 보고된바 있다. ${ }^{19)}$ 알루미나의 유전성에 미치는 불 순물, 기공률 및 결정립 크기 영향 연구에서 이들이 유전 상수보다는 유전손실에 영향이 크고 공통적으로 유전손 실을 높인다고 보고된 바 있다. ${ }^{20)}$

Fig. 6은 여러 가지 알루미나 소재의 절연내력을 측정 한 결과로 유전특성과 마찬가지로 각각의 시편에 대해 부 위별로 3-5회 반복 측정값의 평균(막대그래프의 진한 색 영 역) 및 표준편차(막대그래프의 밝은 색 영역)이다. Fig. 6에 서 보이는 바와 같이 각각의 성형법으로 제조한 알루미 나의 절연내력은 $10.1 \sim 12.4 \mathrm{kV} / \mathrm{mm}$ 범위이다. 가압성형으 로 제조한 $\mathrm{CP}$ 및 $\mathrm{PR}$ 시편보다 필터프레싱으로 제조한 $\mathrm{FP} 2$ 시편이 높은 절연내력을 보이는 것은 불순물 함량이 낮고 치밀한 미세구조에 기인한 것으로 생각된다.

순수 다결정 재료에서 전기전도에 관련된 전하이온의 이동도는 기지와 입계의 공공과 불순물과 같은 결함 농 도에 의해 결정된다. 원자결합력이 강한 많은 순수 산화 물은 결함 이동이 거의 없으며 전도손실이 상당히 낮다. 그러나 $\mathrm{Na}$ 와 $\mathrm{K}$ 와 같은 알칼리 금속은 유리상에서 비교 적 쉽게 이동하여 순수하지 않은 세라믹에서는 입계에 미 량이 존재하여도 상당한 손실을 일으킨다. ${ }^{14)}$

절연체에 전기에너지가 가해지면 재료 내의 구조적인 특징이나 결함에 기인하여 전장이 국부적으로 집중된다. 전기장이 어느 한도를 넘으면 대전류가 흘러서 열이나 기 계적인 stress로 진화되고 드디어 파괴된다. 재료가 절연파 괴 되는 최소 한계전압 $\left(\mathrm{V}_{\mathrm{c}}\right)$ 은 두께 $\left(\mathrm{e}_{\mathrm{p}}\right)$ 와 관련된다. 따라서 절연내력(dielectric strength, breakdown voltage(strength), $\mathrm{E}_{\mathrm{b}}$ ) 은 다음과 같은 관계를 갖고 있다.

$$
\mathrm{E}_{\mathrm{b}}=\frac{\mathrm{V}_{\mathrm{c}}}{\mathrm{e}_{\mathrm{p}}}
$$

다결정 알루미나의 미세구조가 치밀하고 정교하면 상대 적으로 높은 절연내력을 나타낸다. 불순물과 기공과 같은 구조적 결함과 관련된 불균일성이 절연내력을 낮추고 계 면도 절연내력에 영향을 주는 것으로 연구되었다. 알루미 나의 결정립 크기를 낮추면 불순물 이온의 입계 포획 농 도가 증진되어 절연내력을 낮춘다고 알려져 있다. ${ }^{21,22)}$ 알 루미나에 기공(특히 개기공)과 같은 구조적 결함이 존재 하면 절연내력을 낮추고, 실제 전자산업용 장치부재의 사 용환경에서 수분 및 산알칼리가 게재되어 공기 중에서 측 정한 절연내력보다 쉽게 절연파괴를 일으킬 수 있음으로 더욱 주위를 기울여야 할 것이다. 본 연구범위에서는 대 형 알루미나 제조시 가장 미세구조와 순도가 좋은 필터 프레스 알루미나가 가장 우수한 절연내력을 나타내어 전 기장이 강하게 작용하는 장치부재에 사용하는 것이 적합 하다고 판단된다.

\section{4. 결 론}

상업용 알루미나 분말로부터 일축가압, 정수압 성형 및 필터프레스 방법으로 성형체를 제조하고 $1600^{\circ} \mathrm{C}$ 의 가스 로에서 소결하여 대형 평판 알루미나 세라믹스 소재를 제 조하여 체적저항, 유전성 및 절연내력의 전기적 특성을 비교하였다. 대형 알루미나 소재는 $97 \%$ 이상의 밀도, 치 밀한 미세구조를 가지며 $99.75 \mathrm{wt} \%$ 이상의 순도이었다. 알루미나의 체적저항은 $1.7 \sim 7.2 \times 10^{14} \Omega \cdot \mathrm{cm}$ 의 범위이고 필터프레스 알루미나와 같이 순도가 높을수록 높았다. 알 루미나의 유전상수는 10.3 11.5 범위이며, 0.018 0.036 범 위의 유전손실은 가압소결한 알루미나와 같이 불순물과 구조결함이 많을수록 높았다. 절연내력은 $10.1 \sim 12.4 \mathrm{kV} /$ $\mathrm{mm}$ 범위로 불순물 함량이 낮고 치밀한 미세구조를 갖는 필터프레싱 알루미나가 높았다.

\section{Acknowledgment}

본 연구는 금오공과대학교학술연구비에 의하여 연구된 논문으로 이에 감사드립니다.

\section{REFERENCES}

1. H. Toshio, O. Seizo, H. Akemi, K. Kazumasa, K. Nobuhisa, O. Kiichi, S. Yasuo, and S. Suguru, "Preparation of Large Alumina Ceramics by Slip Casting," Annual Report Ceramics Res. Lab., Nagoya Institute of Technology, 10 23-29 (2001).

2. K. Masaki, N. Hisao, and K. Yuraka, "Large-sized Alumina Products for Next Generation LCD (Liquid Crystal Display) Manufacturing(in Japan)," Shinagawa Technical Report, 48 139-40 (2005). 
3. F. Golestani-fard, M. Mazaheri, M. Aminzare, and T. Ebadzadeh, "Microstructural Evolution of a Commercial Ultrafine Alumina Powder Densified by Different Methods," J. Eur. Ceram. Soc., 31 [14] 2593-99 (2011).

4. C.-S. Lin and S.-T. Lin "Effects of Granule Size and Distribution on the Cold Isostatic Pressed Alumina," J. Mater. Pro. Tech., 201 [1-3] 657-61 (2008).

5. S-W. Lee and B-S. Jyeon, "Preparation and Properties of Slip-casted Body using High- purity Alumina Powders(in Korean)," New Mater. Res., 14 77-81 (2002).

6. H.-K. Lee, K.-S. Cho, M.-H. Jang, C.-W. Jang, S.-M. Kim, and M.-Y. Kim, "Characteristics of Large Green and Sintered Alumina Ceramics by Filter Pressing(in Korean)," $J$. Kor. Ceram Soc., 46 [3] 306-12 (2009).

7. D. C. C. Lam and M. Nakagawa, "Packing of Particles(Part 2)-Effect of Extra Pore Volume on Packing Density of Mixtures of Monosized Spheres," J. Ceram. Soc. Jpn., 101 [10] 1204-08 (1993).

8. D.C.C. Lam and M. Nakagawa, "Packing of Particles(Part 3)-Effect of Particle Size Distribution Shape on Composite Packing Density of Bimodal Mixtures," J. Ceram. Soc Jpn., 102 [2] 133-38 (1994).

9. I. J. Bae and S. Baik, "Abnormal Gain Growth of Alumina," J. Am. Ceram. Soc., 80 1149-56 (1997).

10. S. H. Hong and D. Y. Kim, "Effect of Liquid Content on the Abnormal Grain Growth of Alumina," J. Am. Ceram. Soc., 84 1597-1600 (2001).

11. K. Sato, H. Abe, M. Naito, T. Hotta, and K. Uematsu, "Structure of Strength-limiting Flaws in Alumina Ceramics Made by the Powder Granule Compaction Process," Advan. Powder Tech., 17 [2] 219-28 (2006).

12. W. Wersing, "High Frency Ceramic Dielectrics and their Application for Microwave Components," pp. 67-119 in Electronic Ceramics, Ed. by B. C. H. Steele, Elsevier Applied Science, London and New York, 1991.

13. F. A. Korger, "Electrical Properties of $\alpha-\mathrm{Al}_{2} \mathrm{O}_{3}$," pp. 1-15 in
Advances in Ceramics, Vol. 10, Structure and Properties of $\mathrm{MgO}$ and $\mathrm{Al}_{2} \mathrm{O}_{3}$, Ed. by W. D. Kingery, The American Ceramic Society Inc, Columbus, OH, 1984.

14. A. P. Goswami, S. Roy, and G. C. Das, "Effect of Powder, Chemistry and Morphology on the Dielectric Properties of Liquid-Phase-Sintered Alumina," Ceram. Inter. 28 [4] 43945 (2002).

15. J. V. Florio, "Dielectric Properties of Alumina at High Temperatures," J. Am. Ceram. Soc., 43 [5] 262-67 (1960).

16. L. M. Atlas, H. Nagao, and H. H. Nakamura, "Control of Dielectric Constant and Loss in Alumina Ceramics," J. Am. Ceram. Soc., 45 [10] 464-71 (1962).

17. C.-L. Huang, J.-J. Wang, and C.-Y. Huang, "Microwave Dielectric Properties of Sintered Alumina Using NanoScaled Powders of $\alpha$-Alumina and $\mathrm{TiO}_{2}, " J$. Am. Ceram. Soc., 90 [5] 1487-93 (2007).

18. J. R. Floyd, "Effect of Secondary Crystalline Phases on Dielectric Losses in High- Alumina Bodies," J. Am. Ceram. Soc., 47 [11] 539-43 (1964).

19. J. Chovanec, D. Galusek, J. Rahe, and P. Sajgalik, "Low Loss Alumina Dielectrics by Aqueous Tape Casting: The Influence of Composition on the Loss Tangent," Ceram. Inter, in press (2012).

20. S. J. Perm, N. McN. Alford, A. Templeton, X. Wang, M. Xu, M. Reece, and K. Schrapelt, "Effect of Porosity and Grain Size on the Microwave Dielectric Properties of Sintered Alumina," J. Am. Ceram. Soc., 80 [7] 1885-88 (1997).

21. L. Haddour, N. Mesrati, D. Goeuriot, and D. Trheux, "Relationships between Microstructure, Mechanical and Dielectric Properties of Different Alumina Materials," J. Eur. Ceram. Soc., 29 [13] 2747-56 (2009).

22. M. Touzin, D. Goeuriot, C. Guerret-Pieourt, D. Juve, and H.J. Fitting, "Alumina Based Ceramics for High-Voltage Insulation," J. Eur. Ceram. Soc., 30 [4] 805-17 (2010). 